5. Out of home [Електронний ресурс]. - Режим доступу : http://old.outof-home.ua/sobitia/finskaya-interaktivnaya-socialnaya-reklama-poblago darila-donorov

6. Wonder [Електронний peсурс]. - Режим доступу : https://www.wonderzine.com/wonderzine/life/news/202123-a-hairraising-message

DOI: http://doi.org/10.31617/k.knute.2019-03-19.16

\title{
РЕКЛАМА ЯК РІЗНОВИД МАСОВОЇ КОМУНІКАЦІЇ
}

\section{Арешенкова-Левченко О. Ю.}

к. філол. н.

КДПУ, Україна

Ключові слова: реклама, рекламна комунікація, рекламна інформація, рекламний текст.

Keywords: advertising, advertising communication, advertising information, advertising text.

Сучасна реклама - це дієвий інструмент впливу на адресата, здатний трансформувати, модифікувати світогляд, свідомість, поведінку людини. Основне завдання комерційної реклами - забезпечити попит на певні товари / послуги та максимально розширити кількість потенційних покупців. Ця прагматична настанова досягає успішного результату через комунікативну стратегію реклами: інформування, переконання, вплив і примус вибрати рекламований товар / послугу.

Жорсткі фінансові умови як один 3 екстралінгвальних чинників реклами вимагають максимальної компресії повідомлення, особливої щільності змісту, частина якого або не вербалізується, або символізується. Тому особливістю реклами є поєднання вербального блоку та невербальних компонентів: візуально-графічних (шрифт, колір, художні елементи, просторово-композиційні рішення, зображення, відеоряд), кінетичних (жест, поза, міміка) та аудіальних (інтонація, ритм, аудіочастини реклами).

Масове поширення інформативних повідомлень реклами дає підстави віднести ії до однієї з форм масової комунікації (Л. Антонова, Ф. Бацевич, С. Бибик, І. Білодід, І. Вікентьєв, С. Гузенко, Т. Джига, Т. Добросклонська, О. Зелінська, В. Зірка, С. Квіт, Н. Коваленко, М. Кохтєв, А. Лященко, О. Назайкін, Б. Обритько, А. Овчаренко, В. Різун, 
Д. Розенталь, Д. Теркулова, С. Тюріна, Н. Удріс, Н. Фурманкевич, Л. Хавкіна та ін.).

Масову комунікацію фахівці визначають як процес поширення інформації (знань, духовних цінностей, моральних та правових норм та ін.) за допомогою технічних засобів (преса, радіо, кінематограф, телебачення) на кількісно великі, розосереджені аудиторії [4, с. 7] задля впливу на оцінки, погляди та поведінку людей [12, с. 348]. За кількістю масова комунікація передбачає більше тисячі учасників [7, с. 7]. Така комунікація завжди публічна, тобто принципово доступна для кожного [3, с. 12]. Масова комунікація сьогодні - інструмент нової ери інформаційних революцій, коли услід за «природними» контактами 3'являються «технічні» [6, с. 295]. Ураховуючи сказане, масову комунікацію слід розглядати як складний процес, що має такі характеристики:

- повідомлення формулюється професійними адресантами;

- масовокомукікаційні тексти надсилаються швидко і безперервно за допомогою ЗМI;

- такі тексти поширюються відповідно до величини та складу масової аудиторії, яка звертає увагу на ЗМІ різними шляхами;

- окремі реципієнти інтерпретують повідомлення згідно зі своїм досвідом, що більшою чи меншою мірою співвідноситься з намірами ініціаторів;

- унаслідок засвоєння отриманої інформації аудиторія зазнає певного впливу, а це означає, що комунікація має успішний ефект.

Реклама створюється за особливими законами, характерними для масовокомунікативного процесу, що відбувається в масштабах суспільства, має семіотичний характер, є організованим, систематичним спілкуванням, яке здійснюється за допомогою різних каналів комунікації $[1$, с. 7]. Тому серед масової комунікації виокремлюється й рекламна комунікація - «сучасний рекламний механізм, один із різновидів масової комунікації зі специфічними критеріями та параметрами якості» [2, с. 77]. Рекламна комунікація грунтується на поглибленому вивченні психології людей, їхніх потреб для забезпечення ефективного впливу [1, с. 7].

Складовими рекламної комунікації є адресант (особа / фірма / агенція, що забезпечує рекламну комунікацію, відправник рекламного повідомлення) та адресат (споживач, що сприймає інформацію). Комуніканти характеризуються множинністю, роз'єднаністю у просторі та часі. Рекламне звернення адресується аудиторії, яка є неоднорідною за складом, різною за поінформованістю, за соціально-економічними параметрами тощо. Поділяють процес рекламної комунікації на такі 
фази: кодування (розробка концепції реклами) $\rightarrow$ сприйняття $\rightarrow$ передача рекламного звернення $\rightarrow$ взаємодія [2, с. 77 ; 5 , с. $63 ; 10$, с. 83].

3 огляду на сказане вище, можемо стверджувати, що рекламною комунікацією є процес поширення рекламної інформації до кількісно великих, різних за складом аудиторій споживачів товарів / послуг за допомогою 3МI.

У свою чергу, рекламна комунікація є одним із видів комунікації соціальної $[8$, с. $12-13 ; 11$, с. 4], адже реклама не існує поза межами людського спілкування. Соціальні комунікації технологічні, вони забезпечують функціонування ідей, відомостей, поглядів та ін.; стратегічні; системні; організовані; публічні; мають діяльнісний характер, перетворюють спілкування в комунікативно-виробничу діяльність; передбачають продукування ідей, відомостей, поглядів тощо у вигляді різного типу творів (інформаційне виробництво); не можуть існувати без соціальної пам'яті; тримаються не тільки на моральноетичних засадах, а й мають правову основу [9, с. 36].

Визначають основні функції соціальної комунікації: 1) інформаційна (передача інформації); 2) експресивна (здатність передавати не тільки змістовну, але й оцінну інформацію); 3) прагматична (здатність передавати комунікативну настанову, яка дією наказу здатна впливати на адресата). Усі вони (функції) наявні в комунікації рекламній, оскільки формування взаємозв'язку, спроба встановити канали спілкування рекламодавця з його аудиторією $є$ суттю реклами [10, с. 79-82].

Отже, специфікою рекламної комунікації $є$ не лише інформування реципієнта про товари / послуги, але й вплив на нього за допомогою різних засобів. Реклама, таким чином, здійснює певну корекцію поведінки адресата, що є основою комунікації впливу.

\section{Список використаних джерел}

1. Гузенко С. Типи комунікативних регістрів рекламного дискурсу / Світлана Гузенко // Вісник Львівського університету : Серія : Філологія. - Львів : ЛНУ, 2004. - Вип. 34. - Ч. 2. - С. 385-391.

2. Іванченко Р. Г. Реклама : словник термінів / Р. Г. Іванченко. - К., 1998. - $207 \mathrm{c}$.

3. Квіт С. Масові комунікації : [підручник] / Сергій Квіт. - К. : Видавничий дім «Києво-Могилянська академія», 2008. - 206 с.

4. Леонтьев А. А. Психолингвистические проблемы массовой коммуникации : [монография] / Алексей Алексеевич Леонтьев. - М. : Наука, 1974. - 147 с.

5. Обритько Б. А. Реклама і рекламна діяльність : [курс лекцій] / Борис Абрамович Обритько. - К. : МАУП, 2002. - 240 с. 
6. Ольшанский Д. В. Психология масс / Дмитрий Вадимович Ольшанский. - СПб. : Питер, 2002. - 368 с.

7. Почепцов Г. Теория коммуникации / Георгий Почепцов. - М. : Рефлбук, К. : Ваклер, 2001. - 565 с.

8. Рекламный дискурс и рекламный текст : [кол. монография] / науч. ред. Н. Т. Колокольцева. - М. : Флинта : Наука, 2011. - 296 с.

9. Різун В. В. До питання про соціальнокомунікаційний підхід у науці / Володимир Володимирович Різун // Комунікація : Влада - медія суспільство. - К. : К.І.С. - 2010. - № 1. - С. 27-37.

10. Ромат Е. В. Реклама : [учебник] / Евгений Викторович Ромат. -3 е изд., перераб. и доп. - К. ; Х. : НВФ Студцентр, 2000. - 480 с.

11. Теркулова Д. Р. Лингвостилистичекские и коммуникативнопрагматические особенности английского рекламного текста : автореф. дис. на соискание учен. степени канд. филол. наук : спец. 10.02.04 «Германские языки» / Дина Раильевна Теркулова. - М., 2004. -24 c.

12. Философский энциклопедический словарь [сост. Л. Ф. Ильичева и др.]. - М. : Современная энциклопедия, 1983. - 840 с.

DOI: http://doi.org/10.31617/k.knute.2019-03-19.17

\title{
СОЦІАЛЬНА РЕКЛАМА: СУТНІСТЬ, КЛАСИФІКАЦІЯ ТА ОСОБЛИВОСТІ РОЗВИТКУ
}

\author{
Балук Н.Р. \\ к.е.н., доцент \\ Басій Н.Ф. \\ к.е.н., доцент \\ Дайновський Ю.А. \\ д.е.н., професор \\ кафедра маркетингу \\ ЛТЕУ, Україна
}

Ключові слова: сочіальна реклама, тип соціальної реклами, суспільні иінності.

Keywords: social advertising, type of social advertising, social values.

Основна мета комерційної реклами - продати продукт, тобто все, що може бути об'єктом маркетингу. Основна мета некомерційної реклами - змінити ставлення громадськості до певних явищ, подій, цінностей та ситуацій, а також створення нових суспільних цінностей, 